Paskins author copy.

https://doi.org/10.1016/j.shpsa.2019.08.001

Published in Studies in History and Philosophy of Science, 81 (2020): 82-95.

This author copy is shared under a CC BY-NC-ND license.

This means you are free to:

Share - copy and redistribute the material in any medium or format

Under the following terms:

Attribution - You must give appropriate credit, provide a link to the license, and indicate if changes were made. You may do so in any reasonable manner, but not in any way that suggests the licensor endorses you or your use.

Non-Commercial - You may not use the material for commercial purposes.

No-Derivatives - If you remix, transform, or build upon the material, you may not distribute the modified material.

No additional restrictions - You may not apply legal terms or technological measures that legally restrict others from doing anything the license permits.

(Thanks to Creativecommons.org for the summary of this license). 


\section{History of Science and Its Utopian Reconstructions}

\section{Introduction}

Since the sixteenth century, 'utopia' has named the place which is not a place, which is also a good place, or a way of thinking what a good place could be, if one existed. Emerging from European voyages of conquest and discovery, and predicated on a coloniser's vision of empty spaces which could be filled with good societies, utopian desires shifted during the eighteenth and nineteenth centuries to focus on desirable future societies, rather than remote islands (More 1965 [1516]; Marin 1993; Houston 2016). As the term is used in contemporary social theory, utopia refers to imaginary visions of good societies, real-world attempts to carry out such schemes, and the more inchoate longing that things could be different involved in everyday activities like daydreaming, engagement with works of art and shopping (Levitas 2007; Beaumont 2006; Maclaran 1998; Badot and Filser 2007). Utopia is also often invoked to criticise simplistic and totalising schemes which have disastrous consequences, especially the transformative projects of revolutionary and Messianic movements (Gray 2007).

Just a few years ago, even defenders of utopia wrote with the assumption that the concept was at best embattled and at worst dead, except when it was promoted from the political centre. By the mid-2000s major utopian schemes were considered post-ideological and pragmatic; as one scholar who sought to assert the value of utopian hope lamented, more than ever we have become narrow utilitarians dedicated to fixing, not reinventing, the here and now" (Gray 2008; Jacoby 2005, p. ix). These arguments are consistent with a wider vein of criticism according to which it has become increasingly difficult to entertain really different imaginations of the future, except in terms of catastrophe (Fisher 2009, Jameson 2003). But over the past few years a reinvigorated utopianism has reappeared across the political spectrum. From the left, a number of popular books with titles like Inventing the Future, Four Futures, and Utopia for Realists, have sought to rekindle utopian aspirations by imagining how new technological developments could be deployed for social benefit (Srnicek and Williams 2015; Bregman 2017; Frase 2016). Among libertarians, discussions of Sea-Steading, the construction of floating communities in order to escape the constraints of the nation state, have a powerfully utopian outlook (Friedman and Taylor 2012). And populist political projects, including the administration of Donald Trump in the US and the UK's vote to leave the European Union, have also been interpreted as possessing powerful utopian dimensions (Hitchcock 2016; De Cock, Just and Husted 2018; Guldi 2017).

Many recent utopian visions draw inspiration from the histories of science and technology. Calls for a mass mobilization in response to climate emergency, for example, 
invoke the experience of the Home Front during World War Two, including the enrolment of science (Climate Mobilization 2018). One of the strategists responsible for delivering the Brexit vote has speculated extensively on the prospect of remodelling the British civil service along the lines of NASA and DARPA; arguments which are based on the eclectic readings of histories of science and technology (Cummings 2018). Alex Williams and Nick Srnicek's manifesto Inventing the Future, which tries to imagine how wide scale automation might be redirected for socially progressive purposes, gives a lengthy discussion of Project Cybersyn, the Allende regime's attempt to introduce a socialist version of cybernetics to 1970s Chile, which they learned about from the historian of science Eden Medina's book Cybernetic Revolutionaries (Williams and Srnicek 2015, pps 148-150; Medina 2011). In all these accounts, the scientific and technological past is presented as a resource from which future political struggle could draw inspiration, or which can provide alternative forms and possibilities.

These readings sit at odds with many of the positions and practicesof history and philosophy of science (HPS) and science and technology studies (STS). Scholars in these fields have a long-founded suspicion of utopianism, which they have regarded as simplistic, dangerously totalising, and limiting; I discuss these views in detail in the third section of this essay. Academic analysis of science and technology is supposed to take us beyond delusive fantasies and simplistic myths of progress which are often called utopian, allowing the cultivation of properly ambivalent responses and inclusive accounts which do not ascribe futurity to innovation alone (Segal 2005, pps 156-163, Nowotny 2010). The traditions of STS and HPS are also braided with utopian longings of their own, however: with desires to affirm different ways of knowing, modes of relation and understandings of ontology to mainstream claims made in scientifically advanced societies. Scholars including Karl Popper, Helga Nowotny, Otto Neurath, Bruno Latour, Donna Haraway, and Isabelle Stengers have critiqued what they consider bad utopian visions, but have also advanced their own visions of the good life, meaningful action and the possibility of change. Thus, to give one example, Latour usually talks about utopia to identify positions with which he disagrees. He opposes the separation of 'modern' people's and their practices from those of other human groups, and he gives a story where agency is always distributed between humans and non-humans. As he remarks in a recent interview, "the absolute enemy is utopia" because it requires an imagination of pure, empty spaces, a view from nowhere, and the cultivation of purified categories (Latour, Stengers, Tsing, 2018, p. 592). But, as Lisa Garforth observes, with the same breath Latour also calls for "a new kind of civilization", which is to be based on an "alternative narrative [...] of who we are which will allow us to "participate in a renegotiation of "what we might become"" (Garforth 2016, p. 104, citing Latour 2013, pps. 22, 16). These are different views of what utopia should be, but Latour is far from alone in wanting a more critical and processual 
view of utopian possibility. What is at stake is what Utopianism can mean, and how criticisms of other people's bad dreaming constructs space for alternative visions to flourish.

This essay undertakes to reconstruct the utopian perspectives of HPS and STS. It argues that for many scholars in both disciplines the scientific past has served as a critical counterpoint to the present, allowing challenges to the present-day social and technical orders. Many thinkers from HPS and STS have also, to different degrees at different historical moments, connected their scholarly work with the theory and practice of political struggle, and have sometimes tried to develop plans of possible futures. I argue that a critical engagement with these legacies can help to clarify the motivations and politics of HPS and STS by casting light on how scholars in these fields think about the place of epistemology and ontology in conceptualising alternate possibilities, solidarities, and violence, and in their uses of historical example and imaginative literature to envisage alternatives. Utopian visions and strugglesand critical struggles with the notion of utopia - have not been abstract, but in many cases have responded to historical events and the failure of longed-for schemes.. The examples of utopianism found within the practices of STS and HPS which are discussed here do not connect straightforwardly with the examples of popular utopianism mentioned earlier in this introduction. But they suggest the hopes which inform analyses of other people's utopias- the positive visions cherished by scholars in these fields.

The structure is as follows. The second section poses a series of questions from the field of Utopian Studies, which open up the question of what is at stake in talking about utopia. The third section discusses some of the major approaches to the term 'utopia' in HPS and STS, discussing utopia as blueprint, as existing alternative (or 'heterotopia'), as simplification, as performative tool, and as ethos. The fourth, fifth, and sixth sections then explore three major utopian strands within HPS and STS: longings for integration in the face of knowledge which has become specialised and divorced from other aspects of existence; the dreams of planners that developing scientific knowledge could be brought under social control and redirected for socially useful purposes; and the threads of feminist analyses of science and technology, where these have been developed in utopian directions. The seventh section takes up the problem of Latour's utopianism, examining both the utopian potentials and the strong anti-utopian currents of his thought. Finally, the eighth section draws some general lessons from the pervasive but often overlooked utopian traditions of HPS and STS.

I discuss thinkers from both HPS and STS, paying particular attention to how they reconstruct versions of the past in order to imagine new ways of going forward in the present and future. HPS and STS are now in many respects different scholarly disciplines, with different methods and concerns. Their separation is, however, a recent phenomenon: in some institutions STS and HPS are taught and researched alongside each other, and there are historians who are also professors of STS (UCL STS 2019). Many important works of STS 
have been historical in character, and STS scholars like Latour and Haraway draw extensively on insights from histories of science, as well as writing historical studies of their own (Latour 1987; Shapin and Schaffer 1985; Haraway 1989). STS practitioners appeal to the works of philosophers and historians as well as others from their own fields; HPS has periodically been invigorated by perspectives from STS as well (Golinski 1998). At the level of longing, struggle and dreaming, the primary focus of this essay, HPS and STS have often reached for one another and that is why they are discussed together here.

Much recent discussion of utopia — both its importance and reasons to resist it — has been framed in terms of the Anthropocene, the putative geological epoch shaped by human activity (Hamilton 2016; Latour 2016; Bennett et al. 2015). Thinking through the transformative potentials and devastating tendencies of the Anthropocene has been central for the thinkers considered in the second half of this paper. In reconstructing the longer legacies of utopian thought and practice in HPS and STS, however, I have not prioritised the concerns of the present with the Anthropocene and what Latour terms the 'New Climate Regime' appearing as the obvious end-point for the other intellectual and political projects discussed here. The utopianism of HPS and STS has been more diverse than this framing would suggest.

Finally, I do not talk about dystopia in this essay, even though visions of radically bad places have been important modes of challenging science and technology, and enjoy wide circulation (Feenburg 2012). The reason for this neglect is that utopian visions, critiques of utopia, and hopes and actions to bring about desirable change, all feed into each other: it is meaningful to talk about how utopian theory relates to utopian practice. The same is not usually true of dystopia.

\section{Questions from Utopian Studies}

The academic field of Utopian Studies considers utopian thought and practice through investigations of literature, real-world utopias, and a more wide-ranging inquiry into social practices of hope. Scholars have drawn particular inspiration from Ernst Bloch's magnum opus The Principle of Hope, originally published in German between 1954 and 1959, and translated into English in 1986 (Bloch 1986 [1954]) Bloch detected utopian wishes in a wide range of everyday activities, from day-dreaming to aesthetic and religious experience. Most of these longings turned out in practice to be fantasies, but they could also be conceived as anticipatory of a different social and political order, in which alternative possibilities for flourishing were available. In Ruth Levitas' summary, for Bloch “[t]he importance of Utopian wishes hinges on the unfinishedness of the material world. The world is in a constant state of process, of becoming. The future is 'not yet' and is a realm of possibility. Utopia reaches 
toward that future and anticipates it. And in so doing, it helps to effect the future" (Levitas 1990, p. 14). Bloch conceived his recovery of past hopes in Marxist terms, emphasising the need to distinguish between idle fantasies and "concrete utopia"; he thus criticised the contents of many of the modes of hope which he discussed (Levitas 1990, Jameson 1974, p. 125). As Levitas observes, Bloch's desire to separate productive struggles and wishes from merely fantastical ones is shared with many other theorists of utopia, and is central to the claim that utopia can get beyond dreaming and contribute to meaningful action-but the distinction isdifficult to ground epistemically (Levitas 1990, p. 13). Nevertheless, critiques of other people's idle utopias can be a way to clarify one's own visions of transformation.

STS and HPS have engaged to a limited degree with Bloch's work, with two collections giving fairly brief discussions of his contributions (Nowotny 1984, Kemperink and Vermeer 2010). There is thus some work to do in clarifying how insights from Utopian Studies relate to the questions and concerns of these disciplines. It is beyond the scope of this essay to give an overview of the entire field, but the remainder of this section poses some questions suggested by utopian studies, which will help to focus our discussion of utopianism in STS and HPS.

Does 'utopia' refer to a small subset of visions of alternatives, or can utopian desires be detected in political projects of all sorts? Karl Mannheim claimed that in democratic cultures, any explicit programme put forward by an opposition party can be considered utopian, in the sense that it challenges the established political order (Geoghegan 2004). Levitas argues that utopian scholars must explicate the visions of a good life implicit in all political programs, including those which identify as centrist or pragmatist, and contrast these with explicit proposals of their own (Levitas 2013, pps. 153-174). This expansive view of utopianism runs counter to the ways in which the term is often used, and risks treating all normative political programmes as utopian. On the other hand, a more restrictive definition of utopia risks presenting utopian hope as a sporadic eruption into the normal order of things, which can mystify the utopian presuppositions which underlie normal conditions. In section three I pay close attention to some of the main ways in which HPS and STS scholars have used the term; the following sections present attempts from within these disciplines to imagine alternative possibilities. Again, these mainly involve explicit invocations of utopia, though some are resistant to the notion; I also try to keep in view the ways in which critics of utopia also advance their own accounts of flourishing. This is a comparatively small subset of the possible utopian visions which could be considered within HPS and STS: I do not talk about the utopian possibilities implicit in, for example, internalist histories of science or upstream science engagement, though each has hopes and visions of change which would certainly bear unpacking (Koyré 1968; Wilsdom and Willis 2004). This is a limitation, but has the advantage that I am able to discuss relatively reflective accounts of (and resistances to) utopianism. 
What activities and resources are used to construct utopias? Utopian Studies haspaid particular attention to works of imaginative literature, paying considerable attention to questions of literary form (Elliot 1970; Suvin 1973; Jameson 2005). It also investigates everyday spaces in which different ways of living are available, activities which involve longings for transcendence, or for things to be different (Levitas 2007; Cooper 2013). Scientific practices may be considered utopian in a number of senses: they can embody hope, or values and ways of relation which challenge habitual ways of acting.

How does Utopian thought relate to other methods of imagining the future? While some utopias are located in the future and associated with notions of progress, many of them are not and in recent years much utopianism can be said to have abandoned the future (Garforth 2009). Nevertheless, utopian thought is closely associated with other attempts to construct desirable futures, for example through plans, manifestos and scenarios (Raven 2015; Weeks 2013). In section five, we will see how scholars who want to revive an ethos of planning but who are sceptical of modernist accounts have turned towards more reflexive modes of producing accounts of the future. Section six considers the important place which utopian science fiction has played in articulating accounts of science, and the turn in Donna Haraway's recent work towards the construction of future scenarios.

How are histories mobilised within accounts of utopia? A major trope of many accounts of utopia is that a tradition of hope and visions of meaningful change have been lost and which needs to be recovered. As part of this recuperation, scholars turn towards the past in order to salvage possibilities and to demonstrate that envisaged alternatives have played a meaningful role in history, even if they have been defeated or marginalised. Levitas, for example argues that around the turn twentieth century, writers including HG Wells, Edward Bellamy, William Morris and Charlotte Perkins Gilman wrote utopian works which point towards a different image of how sociology can be imagined, with a utopian method at its centre. Such possibilities were displaced, according to Levitas, through the institutionalization of approaches which instead tried to present sociology as a mode of value-free scientific inquiry, and which disavowed its utopian connections (Levitas 2014, p. 91-98). This recovered tradition serves in part to legitimate Levitas' own form of inquiry. In the third section of this essay, we will see how practitioners of HPS and STS turn to the past in order to recover more integrated modes of knowledge than often appear available in the present, thus challenging existing orders of knowledge. But the question of which histories are enlisted in this way is crucial: there are many possible modes of integration, and some accounts have favoured aesthetic aspects, while others have stressed epistemic and political ones.

Who and what belongs in a utopia, and how are these humans and other beings formedwhat are their ontologies? A lot of debate about utopia has turned on the question of whether behaviours can be altered in line with the requirements of utopian societies, or whether there 
is an unalterable human nature. Levitas focuses on the question of "what is understood as human flourishing, what capabilities are valued, encouraged, and genuinely enabled, or blocked and supressed, by specific exiting or potential social arrangements [...] the historical and social determination of human nature" (Levitas 2014, p. 153). In recent years, scholars including Bruno Latour, Isabelle Stengers and Donna Haraway have tried to think through the implications of more ontologically inclusive visions of community, though as we will see in sections six and seven, they do not always agree that this is a utopian project. As Garforth puts it, for these thinkers "the world we have made and must inhabit is a messy, dynamic assemblage of the natural, the technological and the human": a picture which as we will see in sections six and seven can have powerfully utopian implications. (Garforth 2017, p. 138).

What solidarities do utopian actions and imaginings involve? Utopian thinkers have approached the question of how to relate their commitments to the struggles of non-academic political movements in a number of different ways. This is sometimes a version of the problem of relating theory and praxis, but can also involve considerations about how analysts should relate to the practitioners they study: as critics, allies, or in terms of a different encounter. As we will see in section four, the problem of solidarity animated the British radical science movement in the 1970s and 80s. As I discuss in detail in sections six and seven, Latour and Stengers approach questions of solidarity very differently, despite similarities in their ontologies.

How have utopian visions and struggles changed? One of the classic complaints about utopias is that they are static and unchanging (Moore 1966). Accounts of utopia also bear the traces of the historical conditions in which they were produced, and the viability of explicitly utopian modes of thought has ebbed and flowed. Marianne DeKoven argues that during the 1960s a modernist form of utopian thought started to give way to a more 'limited', postmodern, version of utopia, attached to a multiplication of identities, notions of internal resistance, rather than radical change. Utopia has become "muted, partial, local, diffuse, multiple, sceptical, complicit, displaced, and significantly refunctioned" (DeKoven 2004, p. 25). During the same period, many positive accounts of utopia have also shifted from fixed blueprints to a more processual and reflexive view. We will see versions of this transformation play out repeatedly in this essay, especially in the legacies of scientific planning considered in section five, and in the developments of feminist thought discussed in section six.

What role does violence play in utopian projects and imaginings? Opponents of utopia have often argued that it seeks to create a perfect society and is prepared to resort to violence to do so. Advocates of utopia reject these claims, but usually do so by distancing themselves from totalitarian political regimes and movements such as the Soviet Union of the 1920s which have exerted considerable fascination for those seeking to imagine alternatives (Bernal 1939). This distancing is achieved in part through a redefinition of what should count as utopian- 
but as recent works by Haraway and Latour make clear, the place of violence in utopian visions cannot be solved by fiat. I discuss this in detail in sections six and seven.

Many of the discussions of utopia in STS and HPS have offered analyses of the utopias of others. In the process, scholars have sometimes articulated visions of their own, as well as giving a host of definitions about what utopias are and the functions which they serve. This is the subject of the next section.

\section{Other People's Utopias}

Definitions of utopia are contested: different interpretations of the term serve as a battleground for treating different visions of the good life, or visions of change as meaningful, fantastical, irrelevant, necessary, or inevitable. Within HPS and STS, utopia tends to be invoked in five main ways: as a blueprint; as an existing alternative or 'heterotopia'; as a simplification; as a performative tool; and as an ethos. What brings these senses together is that they are analyses of other people's wishes and values - even if more normative accounts endorse some of them and not others, they do not generally represent analysts' own cherished hopes. I will consider each of these uses in turn.

Perhaps the best-known denunciations of blueprint utopianism are found in the work of Karl Popper, and is closely related to his philosophy of science. Popper offered a liberal critique of the totalitarianism which he claimed emerged from planned societies, especially those of the Soviet bloc. 'Closed' societies, Popper argued, identify end points in advance and reject serious consideration of the means needed to achieve them. For advocates of planning "rational political action must be based upon a more or less clear and detailed description or blueprint of our ideal state, and also upon a plan or blueprint of the historical path that leads towards this goal" (Popper 1986 [1947], p. 5). Popper claimed that such blueprints would also lead to violence because their advocates could not accept the tendency of politics to wander from fixed ends. This contrasts with Popper's view of the procedures of science, which are open-ended and could not rely on any final settled claims about knowledge, only a series of falsifications of statements which have been proven untrue (Popper 1963, pps. 33-9.) Science could thus serve as a liberal model for resistance to tyranny.

It is now conventional for defences of utopia to distance themselves from the blueprints which Popper deplored (Jacoby 2005; Kumar 2010). Much recent explicitly utopian thought is open-ended and processual, even when it does not endorse Popper's political liberalism. Thus, for example, Jacoby cites Lewis Mumford's disgusted irritation at the empty aridity of many blueprint utopias, which were filled with "rigid virtues [...] frozen institutions [...] static and self-limiting ideals" (Mumford 1959, p. 5, cited in Jacoby 2005, p. 32). Jacoby instead seeks to promote the tradition of "iconoclastic utopias" which did not "elaborate the future in 
precise detail" but rather "longed, waited, or worked for utopia but did not visualize it" (Jacoby 2005, p. 33). We will see some of the ways that similar ways of thinking informed HPS and STS in the following section.

When Popper's arguments are counterposed to other positions regarding the emergent military-industrial-academic science of the Cold War, they retain an insistence on critical thought at odds with positions which view science as bound by community consensus and technical problem-solving. For this reason, Steve Fuller defends Popper's positions against those of Thomas Kuhn (Fuller 2004). In Fuller's reading, Kuhn speaks for a conservative and authoritarian vision of science, which refuses to question associations between scientists and the military industrial complex, while Popper affirms a more critical vocation.

Popper's picture of science can be connected with other studies from a liberal perspective which have understood scientific communities as embodying generally desirable political values. Michael Polanyi's representation of scientific community as "the Republic of Science" has similar implications (Polanyi 1962). Polanyi argued that "in the free cooperation [of scientists] we shall find a highly simplified model of a free society, which presents in isolation certain basic features of it that are more difficult to identify within the comprehensive functions of a national body" (Polanyi 1962, p. 54). The self-coordination of scientists closely resembled rational decision-making and the transmission of information which Polanyi held to characterise the operation of markets as well: "Any attempt to organise the group of helpers under a single authority would eliminate their independent initiatives and thus reduce their joint effectiveness to that of the single person directing them from the centre. It would, in effect, paralyse their cooperation" (Polanyi 1962, p. 56). I return to Polanyi's conflict with the planners of science in section five, below.

These descriptions of science as offering models for a larger political order can be compared with accounts of scientific sites - notably laboratories and the research communities which are organised around them--which stress that they allow alternative values and forms of relation to flourish. Such sites recall Michel Foucault's definition of "heterotopias", as those "real places $[\ldots]$ which are something like counter-sites, a kind of effectively enacted utopia in which the real sites, all the other real sites that can be found within the culture, are simultaneously represented, contested, and inverted" (Foucault 1984 [1967], p. 3). For Foucault, heterotopias are not located in the future; instead they exist alongside and athwart the existing social order, challenging the association between utopia and the future by realising the viable presence of alternatives in the present. The historian of biology Donald Fleming describes one laboratory as "one of the little communities of intellectual purpose and excitement that constitute the only genuine utopias of the twentieth century" (Fleming 1969, p. 179). Paul Josephson's study of the Soviet science city of Akademgorodok presents that city as a place where forms of life were possible which were unavailable in the wider Soviet Union 
(Josephson 1997). Polanyi and Popper present science as a model of ideal community, but also imply that the values which characterise scientific communities are more widely applicable. These heterotopian accounts, by contrast, stress the distance between the communities which they describe and the societies of which they form a part.

Other invocations of utopia in STS and HPS challenge popular utopian images as simplistic fantasies. They argue that these utopias are a sign of immaturity, a belief that problems will be solved by new inventions and discoveries; or that disasters will follow from the same source. Eric Jensen writes that in media discussions of new biomedical technologies, "viewed as harbingers of unprecedented utopian possibilities [...] indicate an impoverished and 'thin' public debate on the issue of human cloning" (Jensen 2008, p. 123). For Peter Weingart and his co-authors, meanwhile, utopia marks an immature stage through which many arguments about new technologies and scientific developments often pass. They describe

a first phase [which] is characterized by far-reaching promises, even utopian visions of the implications of new research lines. These are met with value-bound resistance. The more utopian the promises, the more dystopian are the arguments in opposition to the new knowledge or technology. In a second phase of the debate, this value-bound resistance is gradually overcome as concrete research results are linked to individuals' interests (Weingart, Salzmann, Wormann 2008, p. 382).

For these scholars, utopia indicates a starting point for many debates, and which mature analysis will surpass.

Even thin utopian images of the future can play an important role, however, by motivating action to bring about certain future possibilities. Studies of the Sociology of Expectations explore the performative roles of expectations and promises about science and technology (Borup 2006, Brown and Mike 2003). Promises about the future produced by scientists, funders and others invested in the production of scientific futures "inscribe subject positions, identities and interests; pit utopian or dystopian visions of the future against each other; and align various actors in different roles", even, or especially, when they do not come true (Porter and Randals 2014, p. 203). Most sociologists of expectations argue that utopian visions are thin, and that technological achievements are rarely proportionate to the hopes which they raise; but these analysts also emphasise how powerful promises can shape action in the present and lock possible futures in to particular courses of development (Brown et al. 2003).

With a much wider historical perspective, Helen Tilley, Gayan Prakash and Michael Gordin's edited collection Utopia/Dystopia: Conditions of Possibility also investigates the practical and performative role of utopian and dystopian visions. The editors start from the 
perspective that some historical moments are characterised by a sense that a radical reordering of social existence is within reach, and where images of the future which, in other times and places might serve as idle daydreams or unrealisable possibilities, come to act as resources for mobilising action in the present. Making sense of these times, they argue, "requires excavating the 'conditions of possibility' - even the 'conditions of imaginability'—behind localized historical moments, an excavation that demands direct engagement with radical change" (Tilley, Prakash, Gordin, 2010, p. 2). Individual chapters study, among other topics, the shaping of visions around the Peaceful Atom, interactions between colonial missionary and Xhosa millennial visions of the future, and the utopian place of the street in modernist urbanism (Pinder 2010; Wenzel 2010; Krige 2010). This range of utopianisms is much more varied than the mobilisation of resources within contexts of innovation studied by sociology of expectation, but shares with those studies the sense that utopian visions are primarily a way to make things happen, to define identities and shared visions of the future, and inspire actions to bring them about.

Utopianism has also been treated as a pervasive ethos of societies in which science and technology play a significant part. In 1984, mindful of the Orwellian connotations of the year, Nowotny and Everett Mendlesohn edited a collection entitled Ninety Eighty-Four: Science Between Utopia and Dystopia. In her introduction, Nowotny drew on Bloch to argue that "traces of utopian thinking can be found practically everywhere on the frontiers of science; they recur in mundane and practical embodiments in technological projections of what the future ought to look like" (Nowotny 1984, p. 4). Science pointed towards numerous 'inauthentic' fantasy futures populated by technological marvels, but it also anticipated difficult-to-articulate and as yet unrealised futures. Tracing these visions made it necessary "to identify that part of the project of scientific creativity, which aims to realize a transcendental future" (p. 4). For the most part, though, these scientific and technical longings were reductive and controlling, based on fantasies of mastery over nature. The link between science and utopia could be found "in their common yearning for order [...] Science and technology provided the methods, the content and the ideology to make a certain kind of future thinkable" (Nowotny 1984, p. 8). Such futures assumed increases in rationality and progress: for Nowotny in 1984, such a view looked dubious and threadbare.

All of these approaches to utopia treat it as a phenomenon out there in the world, with realworld consequences, and not as idle fantasy. Most also suggest it is a framing which analysis should try to get beyond, either by entertaining a vision of open-ended process as against fixed ends, or by developing more sophisticated ways of thinking about the effects of new technologies. These ways of talking about utopia do not address analysts' own desires for change, except to the extent that these can temper and complicate the supposedly simplistic visions of the utopians. Yet process and ambivalence can also be powerfully utopian notions, 
and dreaming does not cease when we put aside reductive fantasies. The next section explores the ways in which visions of integration have motivated work in HPS and STS, and have been connected to larger utopian goals.

\section{Integrative Utopianism}

Towards the end of his study of romantic science and technology in post-Napoleonic France, John Tresch writes that he "sought to give a sympathetic hearing to thinkers and builders who saw artistic experiment, scientific research, introspection, technological innovation and social justice as tendrils growing from a common stem, demanding to be grafted or soldered back together - as materials and methods out of which better worlds can be made. Their futures do not belong only to the past" (Tresch 2012, p. 311). This attitude can be called 'integrative utopianism'. It is widespread in STS and HPS and is based on the belief that science is now sundered from other aspects of human existence, and union or reunion of different ways of knowing can lead to new possibilities for knowledge and thriving. Integration can be political, aesthetic, religious, epistemic, or psychological (Mauskof and Schmaltz 2011; Cantor and Kenny 2010). Sometimes, like Tresch, analysts appeal to historical examples to suggest the existence of more integrated modes of knowledge, and that these might provide models for the present. As James Delbourgo remarks, Bruno Latour's recent work calls for a revival of modes of inquiry from the past "where science was not a dictatorship of facts but offered compelling images of nature to move us morally and aesthetically, as in the virtuosic combinations of precision measurement and artistic vision produced by the Enlightenment polymath Alexander von Humboldt" (Delbourgo 2018). Similarly, Joseph Needham's studies of science in China inspired some twentieth century historians of science by making them "enthusiastic about this non-Western form of science that was deeply philosophical and religious and brought humankind into dialogue with the rest of nature", in contrast with more secularised and instrumentalised Western sciences of the late twentieth century (Cantor, 2018).

Important negative and positive appraisals of integration were voiced during the twentieth century. Max Weber's 1918 lecture "Science as a Vocation", a defence of the highly specialised character of modern science, and the separation between facts and values, sought to counter what Weber perceived as the desires for intuitionism, mysticism and immediate experience among German youth, on the grounds that such longings could never be satisfied (Weber 1946 [1922]). One of the most influential calls for aesthetic integration, CP Snow's 1959 Rede Lecture, The Two Cultures, is also one of the most misleading (Snow 1959). Snow, a novelist who had trained as a scientist and who worked for the British civil service, argued that the literary public knew nothing of science and the civil service excluded scientists from 
its upper ranks. This was a seriously misleading picture of the post-war British state. Nonetheless, it provided a catchphrase for the need to overcome division, which continues to be invoked in a fashion which Charlotte Sleigh calls "obligatory but uninspiring", especially in studies of science and literature (Sleigh 2010, p.3; Ortalano 2009; Edgerton 2005). Snow's complaint also helped to shape STS and HPS in institutional terms. Snow was cited in the foundation of the enormously influential Science Studies Unit at Edinburgh University, which was founded in 1966 at the behest of the biologist C. H. Waddington and the astronomer David Edge, who at the time was based at the Science Unit of the BBC. The goal of the unit, they wrote, was "to diminish, from the science side, the separation between the 'two cultures' (of the arts and the sciences), which had recently been highlighted by the novelist and prominent intellectual C.P. Snow" (quoted in Henry 2008).

Tresch's utopians do more than state the need for integration, of course: they are directly involved in struggles to articulate new ways of being, knowing and relating which emerge in part from their science and technology. At some moments, the integrative longings and STS and HPS have played a similar role. Many of the aspirations of HPS and STS were shaped in the political matrix of the New Left during the 1960s and 1970s. During this period, left-wing arguments were pervaded with a critique of modernity which held that it reduced human beings to a "one-dimensional" existence, and that involvement with military-industrial science led to a derangement of reason, focusing on narrow technical considerations at the expense of recognising other values (DeKoven 2004, Berman 1993, Marcuse 2013 [1964]). These critiques sought especially to challenge what they perceived as the derangements of instrumental reason, especially as applied to cold war military planning and the conduct of the Vietnam War (Erickson et al. 2013). They also connected with the many arguments in favour of interdisciplinary and holistic approaches to political problem-solving associated with figures like Buckminster Fuller, which were also based on the idea that knowledge had become too specialised and too siloed (Fuller 1970, Blauvelt et al 2015). Part of the utopianism of this period was conceived in response to the recognition that blueprint utopianism of the sort which had been endorsed by the Communist Parties was too rigid and doctrinal, and needed to be replaced with a more diffuse and personal "education of desire" (Nadir 2010). Within this dispensation, utopia was "not to be found in a particular place or form", but was conceived instead as "a movement toward possibilities." (Bammer 2012, p. 58). It celebrated reflexivity and self-challenge as a way of moving beyond the doctrinal fixities of existing plans (Agar 2008). Some movements by scientists and engineers partook in the utopianism of this era. During the 1960s, argues Matthew Wisnioski, "engineers were among the most reflective thinkers about the possibilities and limitations of their interventions", developing an ethos which was commendable "not because it proscribes [sic] a new way of life, but because it insists our assumptions remain perpetually contested" (Wisnioski 2012, p. 198). 
In Britain, these struggles and critiques found a meeting place in the British Radical Science Movement (Rose and Rose 1979). Gary Werskey, a Marxist historian who was active within the Movement, terms the period 1965-1985 the era of "radical science"; Werskey's own work was dedicated to recovering and reappraising earlier radical traditions within British science, including those of JD Bernal and Joseph Needham (Werskey 1978, 2007). Although, as Alice Bell has noted, some participants in the radical science movement subsequently regarded it as conflict-averse and overly respectable, its participants also attempted to live out their values in ways which involved going beyond the limits of the academy (Bell, 2013). Members of the Movement appealed to activism in the present, alongside historical examples, as offering directions for political action and academic study. They also tried to relate these debates to more encompassing visions of a less divided life. Their debates turned around the following questions:

within radical science itself, how much effort needed to go into the development of theoretical understanding of capitalist science and agitational struggles focused on specific scientific practices, and how could these be most fruitfully related? Second, how could the sum total of radical science activities coexist with and be linked to other forms of left politics, by now a highly fractured warren of political parties and sects, bisected by a huge number of issues-based campaigns, and overlaid with a myriad of Marxisms? Third, how and where did the sum total of these activities sit within the context of all our other life-commitments? (Werskey 2007, p. 432).

Similar commitments and attempts to build solidarity informed the scholarship of this period, as did a sense that action to develop scientific and technological alternatives was likely to arise from the struggles of radicals and trade unionists. In his article "Marx and the Machine" Donald MacKenzie noted recent efforts to develop alternative technologies, including "attempts to embody in technology the virtues of small scale, decentralization, and ecological awareness", and also "attempts from within high-technology industry to alter in fundamental ways both what is produced and how it is produced" which sought to "shift production from military to 'socially useful' products, and also to change the nature of production, to reverse in practice deskilling and the separation of head and hand" (MacKenzie 1984, p. 502). MacKenzie concluded that "by making contingency and choice actual rather than merely hypothetical, they throw into ever-sharper light the ways in which social relations shape technical development. Perhaps too the process can be dialectical, rather than one-way" (MacKenzie 1984, p. 502). The influential social historian of Darwinism Robert Young left the field of academic history to retrain as a Kleinian psychotherapist and launch a book imprint called Free Association Books, which focused on the importance of integrating disparate parts 
of the self and overcoming binaries. Young also founded a journal called Human Nature Review which aimed "to bring into communication the variety of approaches to understanding human nature which have a regrettable tendency to be less touch with one another than they might" (Young 2018).

In Werskey's account, radical science was defeated within the academy—part of the larger eclipse of Marxist critique within science studies. He quotes Young's statement from 1985 that "The ... promise of a reflective and critically self-conscious radical science movement that was apparent in the British Society for Social Responsibility in Science conference on the Social Impact of Modern Biology in 1970 has not been fulfilled" (Young 1985, p. ix, cited Werskey 2007, p. 443). I do not quote this claim to endorse it. Instead I want to remark that, as with Tresch's romantics, a sense of unrealised possibility hovers over the politically integrative vision which Werskey and his colleagues sought to foster. Radical Science becomes, in Werskey's telling, a comparatively brief episode from which future studies in STS and HPS might draw inspiration. This nostalgic approach to the possibilities of the 1970s is mirrored by renewed attention among scholars and activists in the Lucas Plan, with the launch of a successor to the plan in 2016 as well as wider attempts to revive political options developed before the 1980s, which have been widely construed as unviable (Medhurst 2014; The New Lucas Plan 2019). The appeal of these arguments is clear, but they focused attention on exemplary moments of radical change which were then defeated rather than the more ambiguous legacies of those struggles. Calls for integration were produced from specific historical contexts but are sometimes treated as though they are applicable in all contexts. In addition, the argument that epistemic, political and environmental peril arises chiefly from a belief in the divisions of modernity can be taken for granted, and prevent us interrogating the vocations of ultra-specialism. Considering integration as a contested and powerful longing through which scholars have sought to relate their political, religious and aesthetic commitments to their scholarship prevents it from being treated as an ahistorical panaceasomething we should always want, and which is always defeated somehow.

The long-standing sense of lost integration and wishes for its restoration can be contrasted with another utopian theme: the argument that sciences should be planned for social benefit. Unlike integration, planning is not usually treated as an approach with direct lessons for the present on close examination, however, some planners turn out to offer a rich picture of science, which has remained meaningful even when their larger schemes have been abandoned. This is the subject of the next section.

\section{Planning and Pluralism}


One of the utopian horizons of scientific research during the first half of the twentieth century was that it could be brought under rational control and planned to bring about immediate social benefit. In 1984, Nowotny remarked that "the ideal of planning is utopia in action; it has its practitioners and has found its theoreticians as well", and added that scientists' direct involvement in utopian projects "occur[ed] at a time when the conscious planning of a whole society seems to have made its first break-through in the real world, after the first World War when the old Order was crumbling practically everywhere in Europe and the new Order seemed seductively near by" in the scientific achievements of the early Soviet Union (Nowotny 1984, p. 11). This belief in planning was, for Nowotny, a delusive mirage, and from the perspective of 1984 it was hard to understand "the intellectual fascination that radiated from this unique, large scale experiment and to imagine the lingering grip it exerted upon the mind of intellectuals of that time" (Nowotny 1984, p. 12).

In Britain one of the chief political advocates of scientific planning was the crystallographer and historian JD Bernal, although many scientists who were sympathetic towards the Soviet Union described its embrace of planning in glowing terms. Bernal's advocacy forms the background for Polanyi's defence of 'pure science' as operating on the model of a market (Pielke 2014). Bernal himself felt that the only context in which his ideas of planning had achieved something like practical realisation was that of war, and the 'planned science' which he advocated can most plausibly be associated with post-war enterprises such as the British nuclear bomb. As Werskey remarks, the advent of "planned capitalist science" was profoundly dismaying for Bernal (Werskey 2007, p. 421).

Unlike the inspirational defeats of integrative utopianism, visions of planning are rejected because of their institutionalisation and destructive consequences. They do not retain the critical charge of a path not taken. There have been few explicit attempts to revive the kinds of planning which proliferated during the early twentieth century, even among those who are sympathetic to the construction of architectural visions of the future. Thus, for example, the sociologist John Urry, whose final works concern the relations between social science and the future, argues that sociologists should be willing to produce explicit scenarios in order to guide decision-making. Urry also, however, distances himself from the term 'planning', "since that has become an ideologically contaminated term from the era of organized capitalism and social democracy" (Urry 2016, p. 15). Planning is not adequate to cope with the uncertainties and non-linear risks, including those arising from science and technology, which face contemporary societies. In their place, Urry advocates the production of narratively rich and reflexive scenarios. He discusses the origins of such scenarios in their use in the corporate sector, and notes how they combine an analysis of present trends with the identification of credible outcomes, together with plausible actions which might lead from the future to more desirable versions of the future (Urry 2016, pps. 97-99). Scenarios are also, implicitly at least, 
bottom-up and involve many different contributors, in contrast to the rigidity associated with past images of planning.

The works of individual planners turn out to be richer and stranger than denunciations of planning suggest. The prospects of planning allow for critical approaches towards scientific knowledge and the ways in which decisions are made about research, and they were sometimes reformulated in response to historical events. The planner who has received the most sustained scholarly attention in recent years is the Austrian polymath Otto Neurath. Neurath was a typical modernist planner in that he believed advances in science and technology would bring about increasing rational control over their future development (Uebel 2012; Cartwright et al. 2008; Nemeth 1991, 1996). Neurath presented utopia as the vocation of the "social engineer", and "frequently appealed to the sciences as flexible and creative tools for planning" (Reisch 1996, p. 167). Deciding which of several possible plans should be followed required the explicit articulation of alternatives. By showing that the specific development of individual sciences was artificial, Neurath would show how it could have developed along alternative lines. As Elisabeth Nemeth puts it: "Neurath's Utopia was that the scientists' collectively gained consciousness of the artificial and practical nature of their knowledge would lay bare the functioning of science in its entirety and so make it manageable and usable" (Nemeth 1991, p. 291). By explicating and demystifying what scientists knew, the social engineer would help to make their findings accessible to democratic contestation. The social engineer could help to generate these plans, but was unable to rank them; this was an irreducibly political task.

In relation to science, this process of examining plural possibilities extended to the sense that there could always be alternatives and it was always necessary to choose between them:

The scientific approach to reality is, according to Neurath, inevitably utopian: the science which he proposes to us cannot say anything about the 'one' reality since it analyses the 'given' reality by juxtaposing it with other possibilities, thus making it 'only one possible one.' For precisely this reason, science can never reveal 'the' utopia but always only 'groups of utopia.' (Nemeth 1996, p. 12).

In his later work, and against the background of political catastrophe in Europe, Neurath pulled back from belief in the imminence of a socialist reordering of society, focusing instead on creating an encyclopaedia which would demonstrate the unity of science. This work "focuses in concrete terms on the development of an alternative to the images of knowledge and of reality which make us believe that there is no alternative" (Nemeth 1996, p. 13). Alongside Neurath's advocacy of planning, then, is a powerful streak of more critical utopianism, a challenge to given assumptions about science and society and a revelation of the constructed nature of science as a single, unified, enterprise. It is for this reason that the philosophers Nancy 
Cartwright and Lola Fleck champion Neurath's approach towards science: rather than proclaiming a singular, unified science, his works made clear that "world is unified only in action", rather than taken for granted as the natural order of knowledge (Cartwright et al. 2008, p. 256).

Something of Neurath's utopian aspiration to reveal the possibility of alternatives within and alongside the existing order of scientific knowledge have affinities in the work of later philosophers. I will give the example of Hasok Chang's writings on scientific pluralism. (While Chang has written on Neurath, and was Cartwright's doctoral student, I do not mean to suggest that Neurath is a direct inspiration for Chang's philosophy. Instead, comparison of the two allows us to see how similar intuitions about knowledge develop in different historical and institutional contexts (Cat, Cartwright, Chang 1996).) Chang argues that past scientific theories can often be revived and developed further, if they were abandoned for no good reason. Some of the entities which have been given up, including phlogiston and frigorific rays, could have been generative of alternative scientific possibilities: this should be the task of historians and philosophers. This calling, Chang claims, is "intellectual and political", a way to "face up to the fact that suppressed and neglected questions represent a loss of knowledge, actual and potential" (Chang 2004, p. 237). In this mode, Chang writes, the academic discipline of HPS "can recover useful ideas and facts lost in the record of past science, address foundational questions concerning present science, and explore alternative conceptual systems and lines of experimental inquiry for future science" (Chang 2004, p. 237).

Compared to Neurath's, Chang's vision is remarkably modest. It is meant to allow students to ask questions which they cannot ask in the usual course of their studies; and to provide a vocation for the academic disciplines of history and philosophy of science in the training of scientists---a desire for education, more than the education of desire. Nevertheless, Chang's approach allows a range of scientific temporalities to coexist, and for the past as recovered by historians and philosophers, to act as a resource for the recovery of possible alternative scientific futures from the defeats of the past.

In considering the legacies of utopian visions of scientific planning, then, we find a considerable intellectual heritage within HPS, combined with a sense that the larger project and methods of planning cannot be recovered. Bernal's framing of scientific organisation persists as a point of departure for social historians of science, but his arguments for directing research to immediate social utility generally have not been revived. Neurath's holistic utopian vision fragments into the problems of finding new modes to produce desirable futures and the ways in which pluralist philosophers have taken up aspects of his epistemology.

Part of the legacy of planning is its institutionalisation: a success which meant that it could no longer be posited as a critical alternative. The next section discusses the ways in 
which scholars have drawn upon and developed insights from feminism in order to imagine different possibilities for science.

\section{Feminist Threads}

Perhaps the most sophisticated reflection on utopia in HPS and STS has developed in dialogue with feminist theory and activism. The thinkers considered in this section, all of whom are influenced by, if sometimes resistant to, feminism, are utopians in the sense that they accept the following set of connected claims:

a) aq belief that the present-day practices of science can be challenged and transformed.

b) That challenge and transfomratoin can be achieved by forms of knowledge more in tune with the historical experience of women and other oppressed groups.

c) That these forms of knowledge are anticipated by ways of knowing and relating which already exist in the present.

d) And that critique also involves an engagement with imaginative literature, especially science fiction.

Analyses of feminism are often organised in generational terms, with a more essentialist 'second wave'-insisting on women's struggle and often identifying distinctive female kinds of knowledge, and ways of being, opposed to patriarchal norms - giving way to a more ironic and ambivalent 'third wave', which is keen to decentre and deconstruct essentialist notions and binaries, such as the one between nature and culture (Kelly 2005; Baumgardner and Richards 2000; Snyder 2008). Though there are many problems with this generational framing, it does capture some of the development in critical feminist accounts between the 1970s and the 1990s.

Evelyn Fox Keller's biography of Barbara McClintock was widely read as demonstrating that a non-masculine science was possible, with knowledge based on relation and care and opposed to reductionism (Fox Keller 1974). In her contribution to the 1984 volume, Fox Keller argues for the possibility of using maternal love as an alternative model for scientific knowledge. To flesh out this possibility, Fox Keller turns to Charlotte Perkins Gilman's 1915 novel Herland, which offers tantalising hints of a social order-and a science - based on feminine values rather than masculine ones (Gilman 1979 [1915]). The problem with Gilman's novel, Fox Keller writes, is that it is bloodless, giving no meaningful role to erotic love; she concludes that perhaps the feminist theorists of 1984 can provide a 
utopian imaginary of maternal knowledge which is capable of being disturbed by erotic desire (Fox Keller 1984, p. 271).

Carolyn Merchant's 1980 book The Death of Nature: Women and Ecology and the Scientific Revolution depicted the scientific revolution as involving an abandonment of earlier animistic conceptions of the cosmos in favour of starkly gendered language about obtaining knowledge of a feminised nature through torture and rape (Merchant 1980). As Katherine Park notes, Merchant's analytic perspective drew on the critical feminist utopian fiction of the 1970s, and she paid close attention to the utopian writings of the seventeenth century as offering an alternative to Baconian torture-norms (Park 2006). Regarded with a degree of suspicion by many historians of science, Merchant's book has been important for literary historians and especially scholars of early science fiction, by inspiring inquiry into critical approaches towards nascent scientific knowledge during the early modern period.

By the mid-1980s, Sandra Harding was arguing that feminist accounts of science needed to go beyond the exposure of bias and to develop a "successor science", based on "a view of natural knowledge which would bring with it a new form of 'objectivity' supported by a new understanding of the relationship between mind and nature" (Harding 1986; Gatens-Robinson 1991, p. 417). This project could draw inspiration from historical examples like McClintock. As conceptualised by Donna Haraway, successor science was developed into a more partial Utopian mode. Haraway wrote that such studies should aim to provide "a more adequate, richer, better account of a world, in order to live in it well and in critical, reflexive relation to our own as well as others' practices of domination and the unequal parts of privilege and oppression that make up all positions" (Haraway 1988, 579). Haraway's shift in emphasis aimed to bring out the limitations and fragmentation of all perspectives, challenging associations between masculinity and reason, but also insisting on the collusions and violenceof female subject-positions.

Another of Haraway's other major works of the mid-1980s, The Cyborg Manifesto, has found an extraordinarily wide readership within cultural and literary studies as well as within STS. Haraway's cyborg was intended as an ambivalent figure of late capitalism. On the one hand, she celebrated the productive potentials of new technologies, and the new forms of relation and solidarity between partial, situated and embodied knowledges which they could enable, a new world which transgressed boundaries and suggested a post-modern play of possibilities. Haraway's manifesto proposed "the utopian dream of the hope of a monstrous world without gender"; the not-yet, speculative aspect of its figurations was key to its intent (Haraway 1985, p. 181). In Helen Kuryllo's words, Haraway “identifies several areas of boundary breakdown, including that between human and animal, but focuses primarily on the intersection between human and machine" (Kuryllo 1994, p. 50). Haraway also sought to keep in view those who were damaged and disenfranchised by globalised communication systems. 
As Jackie Orr puts it, Haraway "conjures the potent utopian figure of the cyborg as an imaginative resource for feminists facing a night dream of post-industrial society, the scary new networks of coded hieroglyphics that now produce so much more than just the secret ontology of Marx's commodity fetish" (Orr 2012, p. 274). The cyborg is meant to name the processes by which human bodies, machines, flows of capital, and the non-human world become entwined, and offer partial resistance to domination. Some of Haraway's readers saw the affirmative side of this but not the ambivalence, and rejected the manifesto as an uncritical embrace of new technologies (Kafer 2013, p. 103).

Haraway has long turned towards science fiction as an imaginative resource to envisage alternative social and scientific orders (Haraway 1989). She has also argued that her theorisation of scientific practice emerges in part from taking seriously their historical and contingent nature. Thus, although the "Manifesto" is most certainly not a work of historical analysis, Haraway traces its genesis in part to her own awareness of the "radical historicity" of scientific objects and practices:

I loved biology and I seriously, passionately engaged with its knowledge products: its materialities, organisms and worlds. But I also always inhabited biology from an equally powerful academic formation in philosophy [...] I was extremely interested in the way the organism is an object of knowledge as a system of the production and partition of energy, or a system of division of labour with executive functions. This is the history of the ecosystem as an object that could have only come into being in the context of resource managements, the tracking of energies through trophic layers, the tagging apparatuses made possible by Savanah River Nuclear facilities, and the emergence of wartime interdisciplinarities in cybernetic, nuclear chemistry and systems theories. It was never really possible for me to inhabit biology without a kind of impossible consciousness of the radical historicity of these objects of knowledge (Haraway in Gane 2006, p. 135-6).

Part of the ontology informing the Cyborg Manifesto, then, is how scientists would conceive their objects if they took their history seriously, and engaged them with the kind of united sensibility — a joint formation in biology and philosophy—for which integrative utopians have longed. Haraway has subsequently distanced herself from the term 'posthumanism', arguing that it lent itself to interpretations that ignored the material basis of information in favour of the celebration of unlimited and unfettered disembodiment: a technoutopianism which she regards with deep suspicion. Her own critical utopian project has demanded different vocabularies and alternative figurations. 
Haraway's later work has instead talked about different kinds of entanglement which unsettle the categories of the human and of gender. These include non-human "companion species" and SF, a widely ranging term of unstable reference which includes "Speculative Feminism", "Science Fantasy", "Science Fact" and "String Figures"- the last of which is intended to capture the crafty, caring, communal practices of dwelling (Haraway 2003; 2013). The reference is deliberately shifting and playful, but is animated by the desire for a contingent figuration adequate to "propose and enact patterns for participants to inhabit, somehow, on a vulnerable and wounded earth" (Haraway 2016, p. 10). Haraway argues that her work is a kind of reparative speculative storytelling which imagines modes of relation which allow people to abide with ecological difficulty and harm without seeking to escape or transcend it, and recognising the immense damage and unending dying which is likely to ensue. To this end, she writes touchingly about human entanglements in the lives of verminous animals such as pigeons, and the importance of quotidian activities such as composting (Haraway 2016, pps. 31-2). She has also written a fiction of her own, the "Camille Stories". These are multigenerational narratives about how humans and human descendants might be able to survive in the future, premised on the development of modes of kinship (between humans, animals, and other non-humans) less oriented towards biological reproduction (Haraway 2016, pps. 134168).

Haraway's stories retain her earlier work's concern with finding figurations which are adequate to a situation of immense possibility which is also a condition of devastation. The scenario amounts to a kind of playful architecture of a survivable future, without seeking to offer a directive map. It owes a great deal to the utopian and dystopian feminist SF of the 60s and $70 \mathrm{~s}$, and indeed functions as a kind of pastiche of that genre. Some critics have read Haraway's narrative scenario as more architectural than her previous work. She has been criticised for a destructive — even genocidal — utopianism. As Sophie Lewis writes:

Population reduction, as [Haraway] now fantasizes it, is declared by fiat to be nondiscriminatory, friendly, collective, and non-coercive. [...] One would be justified in expecting to get some elaboration on how the removal of 8 billion heads from the total headcount over the next century or so could be non-coercive - indeed, non-genocidal. But there is really only a fable, based around a micro-community in the United States, proclaiming that this is possible. The utopia of 2-3 billion human beings is supposed to arise from a choice, simply, to not make babies (Lewis 2017).

This reading of Haraway is enabled by her decision to leave the speculative and ambivalent mode of her previous utopian writing in favour of a narrative form which offers descriptions of determinate future possibilities. As a story of the steps necessary for a general human 
flourishing, it also seems to step outside the limited and oppositional subject position which Haraway has characteristically occupied in the past. Haraway also emphasises the provisionality of her narrative, how it has been created in collaboration with others and how she hopes it will be developed further in the future. Charitably, one could interpret this as a response to the tension between her own standpoint and the longing for a community adequate to tell a story of a liveable future. In Haraway's words: "Every Camille Story that I write will make terrible political and ecological mistakes; and every story asks readers to practice generous suspicion by joining in the fray of inventing a bumptious crop of Children of Compost" (Haraway 2016, p. 136). This raises the spectre of utopian violence, which more playful modes of utopian writing are able to hold at bay. But Haraway does not consider the violent implications of her scenario directly.

Haraway records that she wrote the first of her Camille stories at a colloquium convened by the philosopher Isabelle Stengers, and it is with Stengers' work that I will conclude this section (Haraway 2016, p. xii). Stengers is extremely sceptical of positions which attempt to offer authoritative criticism as outsiders. Stengers' speculative approach and her suspicion of critique which sets itself up as an external arbiter extends to her reading of imaginative literature. Thus, she writes, "My participation in the field of science studies has $[\ldots]$ been sustained by my experience as a science fiction reader, from which I learned that it is possible to fully affirm that 'social' character of scientific practices without using such affirmation as a general critical weapon" (Stengers 2018, p. 26). And it extends also to her attitude towards utopia: she insists that her position is "not utopian", but she wants "to hold on to a basic kind of ignorance: we still do not know what people are able to do. [...] I want to reclaim the insight of those who explore what people together are capable of achieving in concrete situations and on concrete issues from the starting point that the environment makes us ill.” (Latour, Stengers, Tsing 2018, p. 593). She represents her more oppositional encounters with existing institutions in terms of resistance. In her book Another Science is Possible, she turns to Three Guineas, Virginia Woolf's polemic of 1938, in order to challenge the unacceptable collusions which contemporary science involves. Woolf's "unremittingly tough" analysis and refusal to join up with causes, her identification of "the prestigious English colleges that churn out people who are both conformist and secretly violent, whose capacity for violence flares up when they sense they are in danger" helps Stengers to shape her own insistence on resisting the demands of "this academic world that is being destroyed in the name of excellence" (Stengers 2018b, p. 29). Stengers advocates slowing down and behaving like an 'idiot', who takes things too literally and is prepared to be appalled at taken-for-granted ways of speaking and acting. Thus, she writes, if unemployment is justified by metaphors of economic warfare then people who are made unemployed should be honoured with medals 
and parades, and rewarded as veterans (Stengers 2005). If these honours and recognitions are not being given, there is every indication that it is not a real war.

In place of a masterful critique, Stengers gives a speculative account of how the sciences, and scientists, might develop from the specific perspectives, relations, and interactions involved in their individual fields. Stengers uses the metaphor of an "ecology of practices" to identify the complex interdependencies which scientific work involves (Stengers 2005). A philosopher or critic might wish to address these ecologies, but must not do so from a presumption of masterful critique. To grasp the transformative and relational possibilities of scienitific practice, Stengers uses the metaphor of "reciprocal capture": a scientist enters into relation with the objects which she studies, constructing their possibilities, but is also shaped and situated by those objects in turn (Stengers 2010, 90-1). Each area of scientific inquiry is guided by distinct passions: 'obligations' to allow scientists to make truth claims associated with it in specific ways, and 'requirements' about how it shall be allowed to affect the world within which it is situated (Stengers 2010, pps. 49-50). In articulating her notions of scientific practice, Stengers draws extensively on the works of Bruno Latour, which I consider in detail in the next section. Latour also refers to Stengers at length. While many commonalities exist between their projects, I want to emphasise some of the major differences.

The relational specificity and opportunities for becoming which each scientific practice affords are, in Stengers' telling, betrayed when science is presented in a 'polemical' mode, as though it discovered straightforward universal truths. Such falsely universalising claims are sustained through the disavowal of alternative perspectives; Stengers wants to ask what science and scientists could become if the need for such denials were no longer deemed essential for the sciences to make factual claims, and to address the world (Stengers 2010, pps. 28-41). One of the areas in which her work has been most discussed is in discussions of epistemologies of care, and how these might conduce to alternative modes of knowledge and relation within the sciences (de La Bellacasa 2011). But Stengers' work is at once more forbidding and more welcoming than focus on care implies: she seeks not only to imagine how existing scientific practices could be slightly different, but also the ways in which their whole range of characteristic achievements might be brought into more meaningful encounters with one another, and with other ways of being in the world. The outcome of such meetings can never be decided in advance; it is "an event", whose speculative possibility Stengers calls "Cosmopolitics" (Stengers 2010).

In challenging the disavowals which underpin polemical accounts of science, Stengers has been eclectic in her solidarities while trying to avoid presenting herself as a spokesperson for particular groups. She has reflected on the perturbing effects of engaging with the activism of drug-users' advocacy groups, and neo-pagan activists (Stengers 2008, p. 39). She seeks to extend this solidarity into the past, by addressing the perspectives of sophists and witches. She 
asks how presentations of knowledge in the present day, and most critiques of them, rely on the exclusion of these views. She writes that she seeks to learn from the otherness of these groups without dominating them through her own theorising, instead seeking to preserve the bewildered and inarticulate shock of "the (unsophisticated) cry of those who ask 'what did happen to us?"' (Stengers 2008, p. 49). Stengers' point is to find encounters with the shock and dislocations which comes from dispossession without attempting to make mute and bewildered loss more articulate than it is. The point is not to convert to witchcraft, but to think through the consequences of the fact that witches were once considered sufficiently threatening and powerful to annihilate, and that those who inherit such traditions do so in a knowledge of their brokenness. Engaging with these devastated knowledges and practices is "an adventure, both empirical and pragmatic" which she calls reclaiming: "it does not primarily mean taking back what was confiscated, but rather learning what it takes to inhabit again what was devastated" (Stengers 2008, p. 58).

Many of the concepts developed as part of the feminist account of science have been foundational for STS-from situated knowledges, encounters with non-humans, epistemologies of care, and the possibility of reading speculative literature in order to envisage social and technical alternatives. Different feminist thinkers have, however, differed quite significantly in how they have thought about solidarity and the demands of resistance as opposed to those of articulating developed alternative schemes. A particular strength of these approaches has been their sympathy for perspectives which have been marginalised within the mainstream of natural science. Some similarly generative-and disruptive - ontological insights emerge from the work of Bruno Latour, the subject of the next section. But they are couched in far more combative terms, and this has major implications for Latour's dislike of utopia.

\section{Ontology and Enmity: Bruno Latour and Utopia}

Haraway avers that

Intent on the crucial refusal of self-certainty and pre-existing god tricks [...] Latour turns to a resource - relentless reliance on the material-semiotic trope of trials of strengththat, I think, makes it unnecessarily hard to tell his and our needed new story. He defines war as the absence of a referee so that trials of strength must determine the legitimate authority." [...] sciences (always rooted in practices) are war. Therefore, in Latour's passionate speculative fabulation, such war is our only hope for real politics (Haraway 2016, p. 42). 
In this paragraph, Haraway offers a utopian critique of the work of Bruno Latour. It is a dense argument, and I will return to what she means below. For now, it serves to introduce the fact that the question of Latour's (anti-)utopianism is more fraught than that of any of the other thinkers considered in this paper.

The utopian potential of Latour's work consists chiefly in the implications of the ontology which underwrites his startling redescriptions of scientific practice. Creative scientific research always, for Latour, involves collaboration between human and non-human agencies. Careful attention to these collaborations shows that they leave neither the humans nor the non-humans unchanged: rather, agency is redistributed between them, in ways which upset distinctions between nature and culture, or science and politics. In a polemic attached to the end of his book The Pasteurization of France, this view of agency and trials allowed Latour to present a picture in which scientists could "never hope to do better than politicians" (Latour 1988, p. 210). Subsequent work expands his arguments to argue for a version of political ecology based on the incorporation of non-humans into political community and the shaping of a common world, and to a general anthropological account of the ways in which "the moderns" make sense of the worlds which they construct and inhabit (Latour 2013). Part of Latour's goal in these studies has been to refuse distinctions between modern and pre-modern ways of being and forms of knowledge: in Latour's resonant phrase "we have never been modern" (Latour 1993).

Latour is usually scornful of attempts to integrate disparate domains, because attempts to unify imply acceptance that the initial division had some validity (Latour 2004, p. 57). In the conduct of scientific controversies, Latour argues, we are always producing hybrid entities which mess up existing distinctions - especially the ones between culture and nature. If we could be honest about this, we would stop deluding ourselves about their separation. And, more surprisingly perhaps, social histories of science would have their day, for it would turn out that the links historians have traced between social forces, religious practices, and natural scientific investigations have always been an accurate picture of how the entities of science are formed: "purity would sterilize the sciences: behind the force, the wings of angels are always beating invisibly" (Latour 2017, p. 66).

Latour's 2004 book Politics of Nature provides a fleshed out speculative account of how political institutions would be transformed if his insights about ontology and the activism which he terms "political ecology" were thoroughly absorbed. Lisa Garforth remarks that this book recalls the form of a utopian novel, and that though his "proposals for new political institutions may not be terribly practical — and they certainly lack the charm, detail and realism of the political institutions imagined and described in formal utopian fiction. But as a provocation to think differently about politics, nature and the organization of our common life, 
they are unsettling" (Garforth 2017, p. 143). Latour proposes the construction of a "parliament of things", in which the status of spokespeople for existing political interests, spokespeople for nonhuman interests, and the instruments and media through which such claims are produced and circulated achieve a degree of parity (Latour 1993, pps. 142-145). The tone of the book is irenic and generally optimistic: Latour calls for 'diplomats' who will be able to traverse the worlds of science and politics equally, without deciding in advance how decisions should be made.

In Latour's most recent works, the challenge of what he terms "the new climate regime" permits the provisional possibility of realising the mistakes involved in constructing purified categories and abstraction, and for a fraught kind of homecoming (Latour 2017). In this work, James Lovelock's concept of Gaia plays a central role: Gaia names a non-human world which is active and resists human intentions, refusing to act as a static backdrop. But it is also composed of an immense variety of local interactions, which lead to larger effects without cohering into a totality. In this respect, Gaia can be opposed to visions of "the globe" or "the local" which allow these concepts to be treated in abstraction from specific sets of relations and distributions of agency (Latour 2017, p. 145). Latour writes that the figure of Gaia "is presented here as the occasion for a return to Earth that allows for a differentiated version of the respective qualities that can be required of sciences, politics, and religions, as these are finally reduced to more modest and more earthbound definitions of their former vocations" (Latour 2017, p. 4). Facing Gaia advocates a "course of treatment", which may help to seed the possibility of new ways of going forward, which are less based on corrosive fantasies of mastery and separation (Latour 2017, p. 13).

As I noted in the introduction to this essay, Latour usually regards utopia as the enemy. Other critical accounts of Latour's philosophy note his tendency to make claims which "sound simultaneously reserved and revolutionary", or condemn his "wishful thinking fostered by the misuse, or over-extension, of his theoretical tools" (Whiteside 2013, p. 185; Turner 2014, p. 119). Rather than emphasising partial knowledges and situated resistance, as Stengers and Haraway do, Latour tends to talk as though dominant practices and mainstream institutions will need to transform in response to the emergence of the New Climate Regime. His work shows an abiding fascination for political and scientific centres and metaphors of strength.

Others have used Latour as a foil to articulate their own utopian accounts. Andrew Pickering acknowledges his debt to Latour's ontology, which helps him to articulate the "dance" and free-play involved in interactions between humans and non-humans, especially in the context of cybernetic experimentation (Pickering 2009). But Pickering also distinguishes his own work from Latour's on the grounds that Latour is not concerned with addressing ground-level phenomena. According to Pickering, Latour believes that scientific practices are fine as they are, and problems arise from the false accounts which are given of them. 
Pickering's own accounts of agency are meant to affirm more interactive, searching and plafyful modes of inquiry, which means that he also engages with the history of countercultural practices informed by Cybernetics, including RD Laing's radical approach to the treatment of schizophrenia and Stafford Beer's contributions to cybernetic socialism in Chile (Pickering 2010). These initiatives, Pickering argues, show that cybernetics had a playful and countercultural aspect; they are all also thoroughly immersed in the utopianism of the 1960s. Latour usually aims to investigate mainstream scientific practices, rather than counter-cultural ones.

Latour frames his interventions on political ecology as a speculative extrapolation and refinement of the practice of activists, but also deplores that it has failed to realise its theoretical shortcomings and the misleading ontological positions on which it has often been based. $\mathrm{He}$ does not, as Stengers does, seek to learn from devastated or marginalised positions on their own terms. Thus in a recent interview, Latour argues that political ecology has been theoretically impoverished compared with socialism and communism, whose proponents "have tried to rethink the entirety of Western philosophy to frame fights against inequalities and injustice", but who had "Hegel to help them frame the whole circus" (Latour, Milstein, Marrero-Guillamón and Rodríguez-Giralt, 2018, p. 354). He argues that political ecology has remained committed to an externalised vision of nature, and this is the main thing that is wrong with it; according to Latour this theoretical deficiency has prevented meaningful collaboration between environmentalists and other social movements.

I now want to return to the passage from Haraway with which this section commenced. In Latour's most recent work, enemies have come to play a central role; but he has always liked metaphors which make science sound like fighting. Over the past two decades, one of Latour's preferred articulations for conflict between different positions has been the political theology of Carl Schmitt. Schmitt draws a distinction between 'police actions' where an authority is able to reassert control on the basis of established standards, and states of war where no such external authority exists (Dean 2006). From Schmitt, Latour draws the lesson that conflicts, whose participants cannot appeal to an external arbiter, should be understood as wars. If Schmitt's argument is correct, writes Latour, "one can indeed say that the modernist civilizers never had enemies and modern history has never really witnessed a proper war. Even when fighting fiercely, they always deferred to the authority of an indisputable arbiter, of a mediator far above all possible forms of conflict: Nature and its laws, Science and its unified matters of fact, Reason and its way to reach agreement" (Latour 2002, p. 26). 'Moderns'should be grateful to their enemies for clarifying what is at stake: from henceforth there is no external authority, and conflicts arising from an increasingly indistinguishable science and politics will be resolved through either warfare or diplomacy.

Through this talk of war, Latour quotes from military histories, taking from them the lesson that wars often lead to unforeseen catastrophic consequences; he also holds up the 
example of mass mobilisation during the Cold War as a comparator for the slow pace of response to the New Climactic Regime (Latour 2017, p. 45). But he does not show any interest at all in the empirical or theoretical question of how wars have been fought, the networks of humans and non-humans from which armies are assembled; nor does he have any concept of the civilian. His claim that future wars will not resemble the wars of the past because there will no longer be any kind of police authority is a powerful metaphor, but it also belongs to a long line of claims that future wars will be utterly unrecognisable in comparison with earlier ones (Freedman 2017).

It is not clear why war, as one of the master metaphors of Latour's recent thought should not be subjected to the same examination as 'culture' and 'nature' are. This framing has the advantage for Latour that it allows him talk about a radical change in the stakes of dispute without committing him to any definite political position. Instead, the outcomes of the Schmittian state of war are, primarily, a shift in ontological perspective. This modest processual hope again stands at odds with Latour's more transformative rhetoric:

To arrive unannounced among other peoples and put everything to fire and the sword with the aim of pacifying them in the name of a fundamental and already-constituted peace, is not the same thing, the same mission, with the same tension, as appearing, perhaps with the same violence, the same fire and the same swords, and fighting on the battlefield to decide which common world should be progressively pieced together (Latour 2002, p. 32).

This passage appears to foresee a remade colonial violence, continuous with the old one but with its meanings transfigured by a shift in ontological perspective. But because Latour does not subject Schmitt's concept of war to any kind of critical or empirical analysis, as either a concept or a sociotechnical activity, it is difficult to know how seriously to take such arguments. They use an anticipatory rhetoric to envisage changes whose material and political implications are never clearly articulated. By contrast, Stengers' more cautious speculative approach allows her to speak in terms of possibility and becoming, without committing to the more prophetic registers which Latour employs.

The darkness of this vision sits uneasily with the ebullient tone of Latour's characteristic style. New wars present new "opportunities for peace", Latour argues repeatedly: in this new dispensation, which is really the same as the old one, but stripped of the fantasies which allowed the state of war to be concealed, all sorts of new opportunities for diplomacy will arise (Latour 2016, p. 226). Diplomats are admirable because they are committed to open-ended processes rather than fixed outcomes: "The great quality of diplomats", he writes "is that they don't know for sure what are the exact and final goals - not only of their adversaries but also of their own 
people" (Latour 2002, p. 38). This means that diplomacy can be open-ended and lead to unforeseen outcomes; that "parties to the conflicts may, after all, be willing to alter slightly what they were fighting for" (p. 38). Again, diplomacy is not subjected to any kind of empirical or historical analysis, but he does think that they need to be ontologically careful, for "to behave diplomatically, when one is manipulating materials as explosive as deities, is to require oneself always to begin with the attributes, so as not to fight right away over the substances" (Latour 2016, p. 154). In other words, diplomacy will involve finding common ground on the basis of shared understandings of distributed agency. It is not clear how this relates to any previous form of diplomacy.

This is why Haraway deplores Latour's use of Schmitt. The language of enmity allows for exciting vistas and figurations of how the world might change in response to the realisation that human and natural activity are now thoroughly intermeshed with one another, and always have been. But Latour is vague about what kinds of resistance or solidarity should emerge, and gleeful about the prospect of diplomacy and fighting without dwelling on what these activities will involve. As with Haraway's recent work, one major shortcoming of this most generous and exultant of thinkers is that he has no serious account of utopian violence.

\section{Conclusion: We have often been utopian}

This essay has traced some of the utopian and anti-utopian currents which have informed history, philosophy and sociology of science during the twentieth and early twenty first centuries, including the ideal of integration, the hope associated with planning, the fear of blueprints, the celebration of reflexivity and the place of resistant figures. Other traditions can of course be traced, and the treatment of the ones I have considered here is inevitably partial. I hope, however, that bringing these different approaches together can lead to reflections on the radical foundations of some aspects of HPS and STS, and also challenge the nostalgia which accompanies some reflections on how these perspectives fell into relative eclipse within the academy. In recovering past utopian positions, we should also seek to challenge themespecially the ways in which they continue to inform our assumptions, in unexamined ways. I would like to draw three more general lessons. The first lesson is that utopian themes have played a significant, if not a central, role in HPS and STS. The longings for alternatives and integration, the articulation of alternative ontologies, and the attempts to develop scenarios traced here intertwine with attempts to develop solidarities outside the academy, and to understand how to relate scholarly reflection to political practice. These efforts have been defeated, repeatedly; and they have returned, repeatedly. In general, the form that these visions have taken has changed in line with wider shifts in utopian thought over the past fifty years, 
from a more copious account of change to more partial, situated and resistant modes. But the pace of these shifts has worked themselves out differently in different fields, and even in the works of individual scholars. It is thus important to distinguish between the approaches of, for example, Latour and Stengers, despite the kinship of their writings. With these utopian legacies come some views that are almost default, and deserve a more critical interrogation: when, for example, might reflexivity and integration impede scientific, human and non-human flourishing?

The second lesson is that history has been important for imagining scientific and technological alternatives. Not all alternatives are utopian, but to the extent that they disturb the existing order, these visionscan have radical implications. Scholars have often looked to historical examples (such as McClintock's science) in order to affirm that another world and another knowledge is, indeed, possible. They have also, like Haraway, Chang and Stengers, tried to articulate living relationships between the present and the past. This is part of the way in which some elements of HPS and STS work. Stengers also challenges us to think about the authority assumed by critique, including utopian challenges, and how we might shape accounts which allow closer encounters with the practices of others, by giving up our presumption to pass judgment from outside. What may follow from this is a question about how to situate the use and imagination of historical alternatives - when and where do scientists draw on aspects of the past which seem to point towards different ways of going forward, as part of their own practices, and when do alternatives envisaged by STS and HPS impinge on these alternative historical visions? Conversely, what episodes from the scientific past serve chiefly as a resource for people who are not natural scientists to challenge existing orders of knowledge?

The final lesson is intended seriously, but also as a provocation. In the utopian writings of Otto Neurath, the sense that philosophy of science might support the explication of plans for different societies played a central part. Critical utopianism, by challenging the role of blueprints, has pulled away from this direction, favouring more reflexive and less representational modes of utopianism. At the same time, however, as Levitas argues, "Explicit alternative scenarios for the future are fundamental to any kind of democratic debate" (Levitas 2014, p. xviii) This has been the view of much recent academic work on futures, and also the popular utopians mentioned in the introduction. Can HPS and STS provide these scenarios? Should they want to? The reception of Haraway's story suggests some of the problems which can emerge when academics attempt to draw on the resources of fiction; but her desire to move into a fictional register also indicates an interest in specific and detailed description of what possible futures might look like - which are then meant to be open to collaboration and challenge. It is possible to imagine an STS which developed more thorough-going explicit alternative scenarios, and the roles which history and philosophy might play in furnishing episodes for this enterprise. The well-established critique of whiggism, presentism and 
triumphalism in the history of science has always been based on the claim that the meanings of histories of science should not be determined by the way sciences exists in the present (Jardine 2003).What if they were also shaped by their possible futures?

\section{Acknowledgments}

This paper was funded by the European Research Council (ERC)under the European Union's Horizon 2020 research and innovation programme (grant agreement number 694732NARRATIVENSCIENCE).This 'Narrative Science' project, designed to investigate the functions of narrative in the sciences, is outlined on the website www.narrative-science.org. I would like to thank Jon Agar, Geoffrey Cantor, Lisa Garforth, Kim Hajek, Sophie Osiecki and Sara Peres for comments on earlier drafts, and three anonymous reviewers.

\section{References}

Agar, J. (2008) What happened in the sixties? The British Journal for the History of Science 41.4: $567-600$.

Badot, O. and Filser M. (2007). Re-enchantment of retailing: toward utopian islands, In Carù, A., \& Cova, B. eds. Consuming experience London: Routledge.

Bammer, A (2012) Partial Visions London: Routledge.

Baumgardner, J. and Richards, A. (2000) Manifesta: Young Women, Feminism and the Future. New York: Farrar, Strauss and Giroux.

Beaumont, M. (2006) Shopping in Utopia: Looking Backward, the Department Store, and the Dreamscape of Consumption, Nineteenth-Century Contexts 2: 191-209.

Bennett, E, et al. (2016) Bright spots: seeds of a good Anthropocene, Frontiers in Ecology and the Environment 14: 441-448.

Berman, E. (1993) "Psychoanalysis, rescue and utopia." Utopian Studies 4: 44-56.

Bernal, J. (1939). The Social Function of Science London: Routledge.

Blauvelt, A. (2015) Hippie Modernism: The struggle for utopia. Minneapolis, MN: Walker Art Center, 2015.

Bloch, E (1986) The principle of hope. Oxford: Blackwell.

Borup, M, Brown, N., Van Lenteet, H. Konrad, K. (2006) The Sociology of Expectations in Science and Technology, Technology Analysis and Strategic Management, 18: 285-98.

Bregman, R. (2017) Utopia for realists: And how we can get there London: Bloomsbury.

Brown, N and Mike, M (2003) A sociology of expectations: retrospecting prospects and prospecting retrospects." Technology analysis \& strategic management 15: 3-18. 
Brown, N. , Rip, Rip A., Van Lente, H., (2003) "Expectations in \& about science and technology." A Background Paper for the 'Expectations'

Workshop,https://www.york.ac.uk/satsu/expectations/Utrecht\%202003/Background\%20paper\%20ver sion\%2014May03.pdf, consulted 23.05.19.

Cantor G., (2018) Personal communication, 10.11 .18

Cantor, G., and Kenny, C. (2001) Barbour's Fourfold Way: Problems with His Taxonomy of Sciencereligion Relationships. Zygon 36.4 (2001): 765-781.

Cartwright, N. et al (2008) Otto Neurath: Philosophy between science and politics Cambridge: Cambridge University Press.

Cat, J., Cartwright, N., and Chang H., (1996) Otto Neurath: Politics and the unity of science. In Galison, P and Stump, D, (eds.) The Disunity of Science. Stanford: Stanford University Press: Stanford 347-369.

Chang, H. (2004) Inventing Temperature Cambridge: Cambridge University Press.

Climate Mobilization (2019), Climate Emergency, https://www.theclimatemobilization.org/, consulted 23.05.2019.

Cooper, D. (2013). Everyday utopias: The conceptual life of promising spaces. Durham, NC: Duke University Press.

Cummings, D. (2018): \#29 On the referendum \& \#4c on Expertise: On the ARPA/PARC 'Dream Machine', science funding, high performance, and UK national strategy, https://dominiccummings.files.wordpress.com/2018/09/20180904-arpa-parcpaper1.pdf consulted 23.05.19.

De Cock, C., Just S., Husted E. (2018) What's he building? Activating the utopian imagination with Trump, Organization 25: 671-680.

de La Bellacasa, M, (2011) Matters of care in technoscience: Assembling neglected things, Social studies of science 41.1: 85-106.

Dean, M. (2006) "A political mythology of world order: Carl Schmitt's nomos." Theory, Culture \& Society 23: 1-22.

DeKoven, M. (2004) Utopia limited: the sixties and the emergence of the postmodern. Durham, NC: Duke University Press.

Delbourgo J. (2018) No More Easyjet: On Bruno Latour's “Où atterrir? Los Angeles Review of Books, Sept. 6 2018, https://lareviewofbooks.org/article/no-more-easyjet-on-bruno-latours-ouatterrir/\#, accessed 04.11.18.

Edgerton, D. (2005) CP Snow as anti-historian of British science: revisiting the technocratic moment, 1959-1964. History of science 43: 187-208.

Elliott, R. (1970). The shape of utopia: studies in a literary genre. Chicago: University of Chicago Press.

Erickson, P., et al. (2013) How reason almost lost its mind: The strange career of Cold War rationality. Chicago: University of Chicago Press.

Feenberg, A. (2012) Questioning technology. London: Routledge.

Fisher, M. (2009) Capitalist realism: Is there no alternative? London: John Hunt Publishing. 
Fleming, D., and Bernard B. (1969) The intellectual migration, Europe and America, 1930-1960, Cambridge, Mass: Harvard University Press.

Foucault, M (1986) Of other spaces. Diacritics 16.1: 22-27, originally published 1967.

Fox Keller, E. (1983) A Feeling for the Organism San Francisco: Freeman.

Fox Keller, E. (1984) Science and Power for What? in Mendelsohn, E. and Nowotny, H. eds. Nineteen eighty-four: Science between utopia and dystopia New York: Springer, 261-272.

Frase, P. (2016) Four futures: Life after capitalism. London: Verso.

Freedman, L. (2017). The future of war: A history London: Penguin Books.

Friedman P. and Taylor B. (2012) Seasteading: Competitive governments on the ocean, Kyklos 65: 218-235.

Fuller, R. (1970). Utopia or Oblivion the prospects of humanity. London: Penguin Press.

Fuller, S. 2004. Kuhn vs. Popper: The struggle for the soul of science. New York: Columbia University Press.

Gane, N. (2006) When we have never been human, what is to be done? Interview with Donna Haraway, Theory, Culture \& Society 23: 135-158.

Garforth, L. (2009). No intentions? Utopian theory after the future. Journal for Cultural Research 13.1: 5-27.

Garforth, L. (2016). Review: An inquiry into modes of existence: an anthropology of the moderns, by Bruno Latour, Global Discourse, 6: 140-143

Garforth, L. (2017). Green utopias : Environmental hope before and after nature Cambridge: Polity.

Gatens-Robinson, E. (1991) Dewey and the Feminist Successor Science Project, Transactions of the Charles S. Peirce Society, 27: 417-433.

Geoghegan, V. (2004) Ideology and utopia, Journal of Political Ideologies 9.2: 123-138.

Gilman, C. (1979). Herland London: Woman's Press, originally published 1915.

Golinski, J. (1998). Making natural knowledge: Constructivism and the history of science Cambridge: Cambridge University Press.

Gordin, M., Tilley, H., and Prakash, G. (2010) Utopia/dystopia: conditions of historical possibility Princeton, NJ: Princeton University Press.

Gray J. (2008) Post-American Age, https://032c.com/post-american-age/consulted 23.05.2019.

Gray, J. (2007) Enlightenment's wake: Politics and culture at the close of the modern age London: Routledge.

Guldi, J. (2017) The case for utopia: History and the possible meanings of Brexit a hundred years on Globalizations 14.1: 150-156.

Hamilton, C (2016) The theodicy of the "Good Anthropocene" Environmental Humanities 7.1: 233238.

Haraway, D. (1985) A manifesto for cyborgs: Science, technology, and socialist feminism in the 1980s San Francisco, CA: Center for Social Research and Education. 
Haraway, D. (1988) Situated knowledges: The science question in feminism and the privilege of partial perspective, Feminist studies 14.3: 575-599.

Haraway, D. (1989) Primate visions: Gender, race, and nature in the world of modern science New York; London: Routledge.

Haraway, D. (2003) The companion species manifesto: Dogs, people, and significant otherness. Chicago: Prickly Paradigm Press.

Haraway, D. (2016) Staying with the trouble: Making kin in the Chthulucene Durham, NC: Duke University Press.

Harding, S. (1986). The science question in feminism. Ithaca: Cornell University Press.

Henry, J. (2008) Historical and Other Studies of Science, Technology and Medicine in the University of Edinburgh, Notes Rec. R. Soc. 62 223-235

Hitchcock D. (2016) The Election of Donald Trump and Our Wishful Utopias, https://blogs.canterbury.ac.uk/expertcomment/the-election-of-donald-trump-and-our-wishful-utopias/, consulted 23.05.19.

Houston, C. (2016). The Renaissance utopia : Dialogue, travel and the ideal society London:

Routledge.

Jacoby, R. (2005), Picture imperfect: Utopian thought for an anti-utopian age. New York: Columbia University Press.

Jameson, F. (1974). Marxism and form: Twentieth-century dialectical theories of literature, Princeton, NJ: Princeton University Press.

Jameson, F. (2003). The end of temporality, Critical Inquiry 29.4: 695-718.

Jameson, F. (2005) Archaeologies of the future: The desire called utopia and other science fictions. London: Verso.

Jardine, N. (2003) Whigs and stories: Herbert Butterfield and the historiography of science, History of Science 41.3: 125-140.

Jensen, E. (2008) The Dao of human cloning: utopian/dystopian hype in the British press and popular films, Public Understanding of Science 17: 123-14.

Josephson, P. (1997) New Atlantis Revisited: Akademgorodok, the Siberian City of Science, Princeton: Princeton University Press.

Kafer, A. (2013) Feminist, Queer, Crip Indiana: Indiana University Press.

Kelly, E. A. (2005) Review Essay: A New Generation of Feminism? Reflection on the Third Wave, New Political Science 27(2): 233-243.

Kemperink, M, and Loenieke V. (2010) Utopianism and the Sciences, 1880-1930. Leuven: Peeters. Koyré, A. (1968). From the closed world to the infinite universe. Baltimore: Johns Hopkins Press.

Krige, J. (2010) "Techno-Utopian Dreams, Techno-Political Realities: The Education of Desire for the Peaceful Atom", in Gordin, M., Tilley, H., and Prakash, G. 2010 Utopia/dystopia: conditions of historical possibility Princeton, NJ: Princeton University Press, 151-175.

Krishan, K. (2010). The ends of utopia. New Literary History 41.3: 549-569. 
Kuryllo, H. (1994) Cyborgs, Sorcery, and the Struggle for Utopia, Utopian Studies 5.2: 50-55.

Latour, B. (1988). The pasteurization of France Cambridge, Mass: Harvard University Press.

Latour, B. (1987). Science in action Cambridge, Mass: Harvard University Press.

Latour, B. (1993). We have never been modern. Cambridge, Mass: Harvard University Press.

Latour, Bruno (2002) War of the worlds: What about peace? Chicago: Prickly Paradigm Press.

Latour, B. (2004). Politics of nature: How to bring the sciences into democracy. Cambridge, Mass: Harvard University Press.

Latour, B. (2013), An inquiry into modes of existence. Cambridge, Mass: Harvard University Press.

Latour, B. (2017). Facing Gaia: Eight lectures on the new climatic regime, New York: John Wiley \& Sons.

Latour, B., Milstein, D., Marrero-Guillamón, I., \& Rodríguez-Giralt, I. (2018). Down to earth social movements: An interview with Bruno Latour. Social Movement Studies, 17(3), 353-361.

Latour, B., Stengers, I., Tsing, A. (2018) Anthropologists Are Talking-About Capitalism, Ecology, and Apocalypse, Ethnos 83.3: 587-606.

Levitas, R. (1990). Educated hope: Ernst Bloch on abstract and concrete utopia. Utopian Studies 1.2: $13-26$.

Levitas, Ruth (2007). Looking for the blue: The necessity of utopia. Journal of Political Ideologies 12.3: 289-306.

Levitas, R (2013): Utopia as method: The imaginary reconstitution of society. New York: Springer.

Lewis, S. (2017) Cthulhu plays no role for me, Viewpoint, May 8

2017,https:/www.viewpointmag.com/2017/05/08/cthulhu-plays-no-role-for-me/, (accessed 12.10.18).

Lucas Plan (2019) An Idea Whose Time Has Come? http://lucasplan.org.uk/, consulted 23.05.2019

MacKenzie, D. (1984) Marx and the Machine, Technology and Culture 25.3: 473-502

Maclaran, P. and Stevens, L. (1998), Romancing the Utopian Marketplace in Brown, S. Doherty A. and Clarke, B. Romancing the Market London: Routledge: 172-186.

Mann S. and Huffman D. 2005: The decentering of second wave feminism and the rise of the third wave, Science \& society 69.1: (2005): 56-91.

Marcuse, H. (2013). One-dimensional man: Studies in the ideology of advanced industrial society. (London: Routledge), originally published 1964.

Marin, L. (1993) Frontiers of utopia: past and present. Critical inquiry 19.3: 397-420.

Mauskopf, S., and Schmaltz, T. (2011), eds. Integrating history and philosophy of science: Problems and prospects Dordecht: Springer.

Medhurst, J. (2014). That option no longer exists: Britain 1974-76. London: John Hunt Publishing.

Medina E. (2011): Cybernetic revolutionaries: technology and politics in Allende's Chile. Cambridge, Mass.: Mit Press.

Merchant, C. (1980). The death of nature: Women ecology and the scientific revolution. San Francisco: Harper. 
Moore, W. (1966) The utility of utopias. American Sociological Review: 765-772.

More, T (1965) Utopia. London: Penguin, originally published 1516.

Mumford, L. (1959). The story of Utopias. Magnolia MA: Peter Smith.

Nadir, C. (2010) Utopian studies, environmental literature, and the legacy of an idea: Educating desire in Miguel Abensour and Ursula K. Le Guin. Utopian Studies 21.1: 24-56.

Nemeth, E. (1996) Otto Neurath's Vision of Science, in E. Nemeth and F. Stadtler, eds. Encyclopedia and Utopia; The Life and Work of Otto Neurath (1882-1945) New York: Springer, 7-14.

Nemeth, E. (1991) Otto Neurath's Utopias-The Will to Hope in Thomas Uebel, ed. Rediscovering the Forgotten Vienna Circle, New York: Springer, 285-294.

Nowotny, H. (1984) "Science and Utopia: On the Social Ordering of the Future", in Everett Mendelsohn and Helga Nowotny, eds. Ninety Eight-Four: Science Between Utopia and Dystopia, Dordecht: D. Reidel, 3-18

Nowotny, H. (2010) Insatiable curiosity: innovation in a fragile future. Cambridge, Mass: MIT Press.

Orr, J. (2012) Materializing a Cyborg's Manifesto, Women's Studies Quarterly 40.1/2 273-280.

Ortolano, G. (2009) The two cultures controversy: science, literature and cultural politics in postwar Britain Cambridge: Cambridge University Press.

Park, K. (2006). Women, Gender, and Utopia. and the Historiography of Early Modern Science. Isis, 97(3), 487-495.

Pickering, A. The politics of theory: Producing another world, with some thoughts on Latour. Journal of Cultural Economy 2.1-2 (2009): 197-212.

Pickering, A. (2010). The cybernetic brain: Sketches of another future. (Chicago: University of Chicago Press).

Pielke, R. (2014): In retrospect: the social function of science, Nature 507.7493: 427.

Pinder, D. (2010). The Breath of the Possible: Everyday Utopianism and the Street in Modernist Urbanism, in Gordin, M., Tilley, H., and Prakash, G. Utopia/dystopia: conditions of historical possibility (Princeton, NJ: Princeton University Press), 203-230

Polanyi, M. (1962). The Republic of science. Minerva, 1(1), 54-73.

Popper, K. (1963). Conjectures and Refutations. The growth of scientific knowledge London: Routledge.

Popper, Karl R (1986). Utopia and violence. World affairs 149.1: 3-9. Originally published 1948.

Porter, J. and Randals, S. (2014), Politics of expectations: Nature, culture and the production of space, Geoforum, 52: 203-205.

Raven, P. (2015) Imagining the impossible: The shifting role of utopian thought in civic planning, science fiction, and futures studies, Journal of Futures Studies 20.2 (2015): 113-122.

Reisch, G. (1994). Planning science: Otto Neurath and the international encyclopedia of unified science. The British Journal for the History of Science 27.2: 153-175.

Rose, H., and Rose, S. (1979). Radical science and its enemies. Socialist Register 16. 
Segal H. (2005) Technological utopianism in American culture Chicago; London: University of Chicago Press.

Shapin, S., Schaffer, S. (1985). Leviathan and the air-pump : Hobbes, Boyle, and the experimental life : Including a translation of Thomas Hobbes, Dialogus physicus de natura aeris by Simon

Schaffer Princeton: Princeton University Press.

Sleigh, C. (2011). Literature and science Basingstoke: Palgrave Macmillan.

Snow, C. (2000). The two cultures Cambridge: Cambridge University Press, originally published 1959.

Snyder, R.C. (2008) What is Third-Wave Feminism? A New Directions Essay, Signs 34(1):175-196.

Srnicek, N., and Williams, A. (2015) Inventing the future: Postcapitalism and a world without work. London: Verso Books.

Stengers, I (2018b) Science Fiction to Science Studies, in S. Meyer, ed. The Cambridge companion to literature and science Cambridge: Cambridge University Press, 25-44.

Stengers, I. (2005), The Cosmopolitical Proposal, in Latour, B., Weibel, P., eds. Making Things Public: Atmospheres of Democracy (Karlsruhe : Cambridge, Mass. ; London: ZKM Center for Art and Media Karlsruhe; MIT, 994-1003

Stengers, I. (2008). Experimenting with refrains: Subjectivity and the challenge of escaping modern dualism, Subjectivity 22.1:38-59.

Stengers, I. (2010), Cosmopolitics Minneapolis, Minn; London: University of Minnesota Press.

Stengers, I. (2018). Another science is possible: A manifesto for slow science, London: John Wiley \& Sons.

Suvin, D. (1973) Defining the literary genre of Utopia: some historical semantics, some genology, a proposal and a plea, Studies in the Literary Imagination 6.2 (1973): 121.

Tresch, J. (2012) The romantic machine: Utopian science and technology after Napoleon Chicago: University of Chicago Press.

Turner, C. (2015). Travels without a donkey: The adventures of Bruno Latour, History of the Human Sciences, 28(1), 118-138.

UCL STS (2019) “Science and Technology Studies”, https://www.ucl.ac.uk/sts/

Uebel, T., (2012) Rediscovering the Forgotten Vienna Circle: Austrian Studies on Otto Neurath and the Vienna Circle. (Dordecht: Springer Science \& Business Media).

Urry, J. (2016) What is the Future?, Chichester: John Wiley \& Sons.

Weber 1946 [1917] Science as a Vocation, H.H. Gerth and C. Wright Mills eds. Max Weber: Essays in Sociology Oxford: Oxford University Press, pp. 129-156.

Weeks, K. (2013). The Critical Manifesto: Marx and Engels, Haraway, and Utopian Politics. Utopian Studies 24.2: 216-231.

Weingart, P. Salzmann, C., Wormann, S. (2008) The social embedding of biomedicine: an analysis of German media debates 1995-2004, Public Understanding of Science 17: 381-396. 
Wenzel, J. (2010) "Literacy and Futurity: Millenial Dreaming on the Nineteenth-Century Southern African Frontier", in Gordin, M., Tilley, H., and Prakash, G. Utopia/dystopia: conditions of historical possibility Princeton, NJ: Princeton University Press, 45-72.

Werskey, G. (1978). The visible college London: Allen Lane.

Werskey, G. (2007) The Marxist Critique of Capitalist Science: A History in Three Movements?, Science as Culture, 16:4: 397-461.

Whiteside, K. (2012). A representative politics of nature? Bruno Latour on collectives and constitutions. Contemporary Political Theory, 12(3), 185-205.

Wilsdon, J. and Willis, R. (2004) See-through science: Why public engagement needs to move upstream. London: Demos.

Wisnioski, M. (2012), Engineers for change: Competing visions of technology in 1960s America. Cambridge, Mass.: MIT Press.

Woolf, Virginia (2014). Three Guineas London: Houghton Mifflin Harcourt, originally published 1938.

Young, R. (2018) Bob Young's website - Human Nature, http://human-nature.com/, accessed 4.11.2018.

Young, R. (1985) Darwin's metaphor : Nature's place in Victorian culture. Cambridge: Cambridge University Press. 